This item was submitted to Loughborough's Research Repository by the author.

Items in Figshare are protected by copyright, with all rights reserved, unless otherwise indicated.

\title{
Young people and contemporary politics: committed scepticism or engaged cynicism?
}

PLEASE CITE THE PUBLISHED VERSION

PUBLISHER

(C) Frank Cass

LICENCE

CC BY-NC-ND 4.0

\section{REPOSITORY RECORD}

Wring, Dominic, Matt Henn, and Mark Weinstein. 2019. "Young People and Contemporary Politics: Committed Scepticism or Engaged Cynicism?". figshare. https://hdl.handle.net/2134/1087. 
This item was submitted to Loughborough's Institutional Repository (https://dspace.lboro.ac.uk/) by the author and is made available under the following Creative Commons Licence conditions.

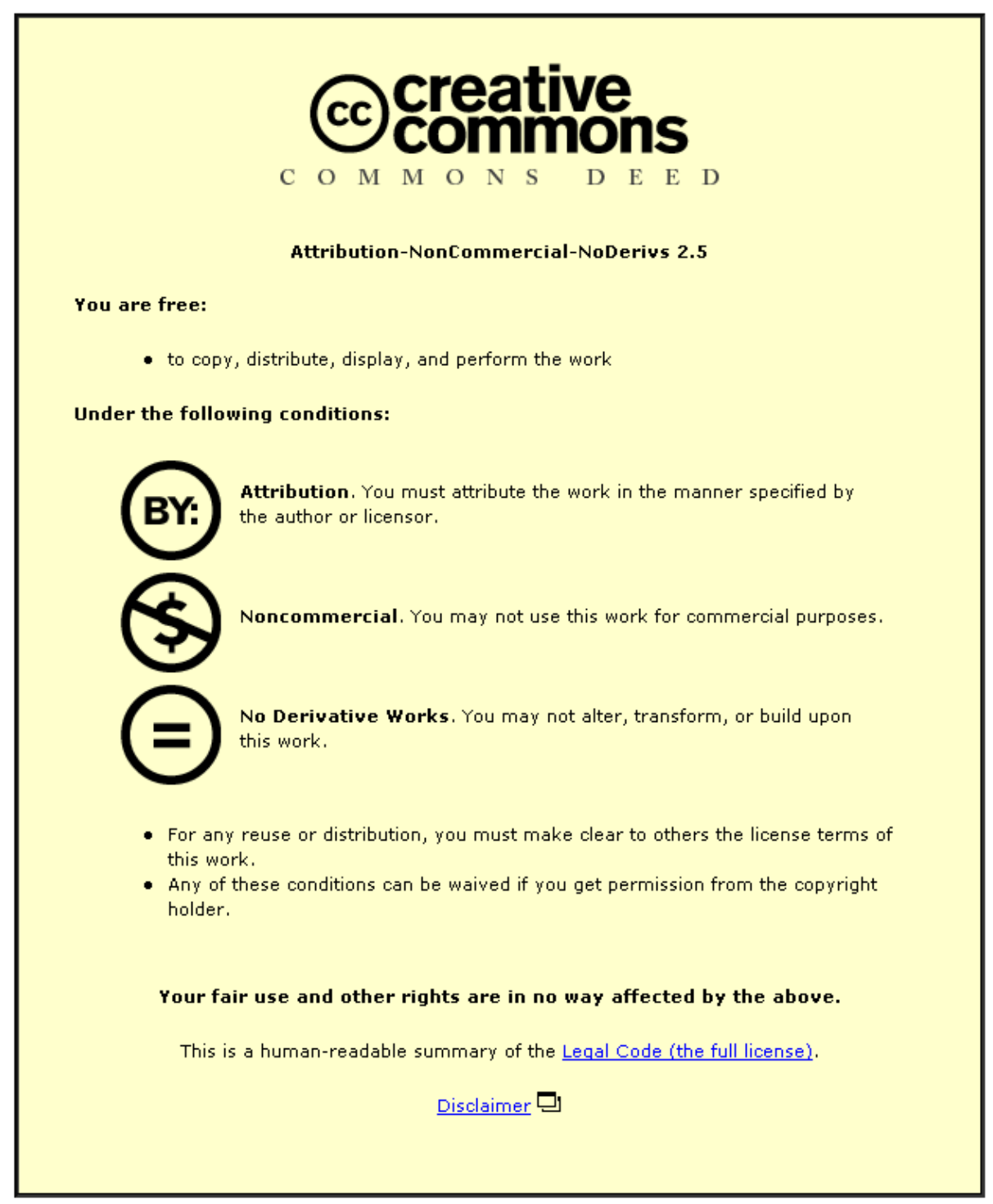

For the full text of this licence, please go to: http://creativecommons.org/licenses/by-nc-nd/2.5/ 


\section{Loughborough University}

Wring, D., Henn, M. \& Weinstein, M.(1999) 'Committed Scepticism or Engaged Cynicism? Young People and Contemporary Politics', in Fisher, J et al.(eds.) British Parties and Elections Review, 9, London: Frank Cass, pp.200-16. ISBN 0714650153 


\title{
Committed Scepticism or Engaged Cynicism? Young People and Contemporary Politics
}

\author{
Dominic Wring, Matt Henn and Mark Weinstein
}

\section{Introduction}

Growing concern about public disaffection with the British political process and its institutions has manifested itself in a number of ways. Whilst some have addressed the apparent decline in electoral participation, others have sought to assess and understand the motivations and interests of specific groups within the population such as women and those belonging to ethnic minorities. ${ }^{1}$ Recently, attention has also begun to focus on young people's engagement with the political process. This concern was borne out by a campaign launched in the run-up to the 1997 General Election. Backed by a cross-party alliance, the music industry initiative Rock the Vote urged young people to make sure they were entered on the electoral register so that they might exercise their democratic rights. ${ }^{2}$ Symbolically the campaign’s May 1996 launch event took place at the prestigious Ministry of Sound club in London’s West End. In promoting itself Rock the Vote attempted to reinforce the idea that, collectively, the youth vote could play a potentially important role in British politics.

There is a perception that young people are increasingly seen as being politically important. During the last general election the victorious Labour Party made a concerted effort to target youth with a specially produced promotional video and advertising in magazines and even nightclubs. ${ }^{3}$ Similarly, following their defeat, the Conservatives opted to elect William Hague as their new leader in a clear vote of confidence in youth over experience. Hague, in a bid to make his age part of his appeal, has talked of a 'fresh start', worn a baseball cap and attended the Notting Hill carnival.

\section{Young People and Political Participation.}

\section{The Political 'Know-nothings'?}

During the 1997 General Election a number of prominent journalists criticised young people for their apparent detachment from the democratic process. Taken together these commentaries have helped to cement a popular conception of the nation's youth as lazy, disinterested and apathetic. Writing in The Times, Nigella Lawson suggested that those young people who complained of feeling marginalised and disenfranchised from the political system:

'... should be treated with contempt... Look here, dimbo, I want to say: by refusing to vote you are disenfranchising yourself. It's no good moaning about which ever party gets in later and claiming that it's not your fault as you didn't vote for them: it will be your fault, absolutely your fault. ${ }^{4}$

Continuing in much the same vein, Polly Toynbee dismissed many youths as 'airheads' and 'know-nothings'; 'they are the don't vote, won't vote, don't give a damn, and they're smug and self-righteous about it too.' ${ }^{5}$ Moreover, Evening Standard columnist Anne Applebaum denounced those young people who 'naturally blame politicians for their apathy' for being 'intellectually lazy. ${ }^{6}$ Comments such as these have led Axford and Huggins to conclude that the nation's media have been complicit in creating an image of a youth population self-consciously cultivating its own 'designer cynicism..$^{7}$

\footnotetext{
${ }^{1}$ See, for instance, Shamit Saggar 'The dog that didn't bark: Immigration, race and the election', and Lucy Peake 'Women in the campaign and in the Commons', in Andrew Geddes and Jonathan Tonge (1997eds) Labour's Landslide: the British General Election of 1997. Manchester: Manchester University Press.

${ }_{2}^{2}$ Martin Cloonan and John Street (1997) 'Popular Culture and Politics', Politics, 18: 1, pp. 33-38.

${ }^{3}$ Labour went as far as placing adverts in club toilets with stickers bearing the legend 'Now wash your hands of the Tories', Dominic Wring, 'The Media and the Election', in Geddes and Tonge (1997).

${ }^{4}$ Nigella Lawson (1997) 'There's no excuse for not voting', The Times, 9 April.

${ }^{5}$ Polly Toynbee (1997) 'Mrs Thatcher's airhead revenge', The Independent ${ }_{2} 28$ April.

${ }^{6}$ Anne Applebaum (1997) 'Don't care, won't vote - what a cop out by "yoof” ', Evening Standard, 20 March.

${ }^{7}$ Barrie Axford and Richard Huggins (1997) 'Young People and Political Marketing: Untargettable or Sentimental at Heart?', paper presented to Images of Politics: International Conference on the History and Development of Political Communication on Television, Amsterdam, October 23-25.
} 
Aside from journalistic commentaries, the perception that young people are politically alienated is reinforced by their apparent reluctance to go to the polls. During the run-up to the 1997 elections there was public concern about the predicted low turnout of the youth vote. ${ }^{8}$ On polling day itself Gallup reported that only 57\% of $18-24$ year olds said they would definitely vote compared with $86 \%$ of people in the $45-64$ age group. ${ }^{9}$ The figures would appear to confirm a trend. In the previous national election of 1992, only $61 \%$ of $18-24$ year olds voted compared with a general turnout of $77.7 \%{ }^{10}$ In 1997 this figure was $71.4 \%$, the lowest poll since the war. This would suggest a further decline in the number of young people voting. ${ }^{11}$

In their detailed examination of electoral turnout, Crewe, Fox and Alt suggest that the relationship between age and participation is relatively straightforward. Put simply: 'the younger an elector, the less likely he or she will vote regularly. ${ }^{12}$ Regular turnout appears to increase with length of residence, age, marriage and a variety of other factors that involve people in national and personal networks. Most importantly, however, Crewe and his colleagues emphasise the distinction between the 'alienated abstainer', who, they assert are 'a minuscule minority of the electorate as a whole', and the more common 'apathetic abstainer. ${ }^{13}$ It would appear that it is apathy and indifference that keep people away from the polls. This assertion finds some support from the work of Bynner and Ashford, authors of a study based on a longitudinal survey of several 16 to 20 year olds living in four different areas of the UK. They identify several explanations for youth disaffection and detachment from the political process. These include young people's negative experience of the education system and early departure from it, as well as their low level of attainment and poor employment prospects. ${ }^{14}$ Bynner and Ashford conclude that whilst apathy is commonly associated with educational failure amongst pre-16s, not voting is connected to a broader range of circumstances and feelings.

The alleged apathy of youth was a major theme of a report from think-tank Demos. Writing in 1996, researchers Wilkinson and Mulgan concluded there was evidence of a 'historical political disconnection'. ${ }^{15}$ The authors went on to tie this to other forms of detachment, specifically the youth population's apparent 'unwillingness to obey the law, to play by the rules, or to pay for the needs of others'. ${ }^{16}$ They theorise that the origins of this disconnection may lie in a more general decline of trust in society's core institutions combined with a frustration borne of unfulfilled ambitions. Nevertheless Mulgan and Wilkinson recognise that young people do care about certain political issues such as environmentalism and animal rights. It is surprising then that the same authors conclude their report with a series of rather mechanistic solutions including recommendations for longer voting periods in elections, polling stations in places like cinemas, and even compulsory voting 'to ensure that young people do indeed exercise their rights'. ${ }^{17}$

\section{An Engaged Cynicism}

In their extensive study of democratic participation, Parry, Moyser and Day make explicit the relationship between political efficacy, cynicism and participation by arguing that cynicism makes less of an impact on participation than a low level of efficacy. Furthermore they contend that, if anything, political cynics tend to be more active. Interestingly they also suggest that:

'to a very large extent, it would appear that participation occurs as a response to some event or issue which has immediate consequences for a person's own life... for the ordinary man or woman in the street, the predominately local issues of the environment and planning head the list. ${ }^{18}$

\footnotetext{
${ }^{8}$ The Financial Times reported that only just over $50 \%$ of first time voters were likely to use their vote; 'Apathy rules amongst electorate's political babies', The Financial Times, 7 April 1997.

${ }_{9}$ Anthony King (1997) 'Eighteen today and voting for the first time', Daily Telegraph, 1 May.

${ }^{10}$ David Butler and Dennis Kavanagh (1997) The British General Election of 1997. Hampshire: Macmillan Press, p.254.

${ }^{11}$ MORI/Rock the Vote figures, January 1997, quoted in London Youth Matters (1997) 'The kids are alright? What it's like to be young in London in the 1990's'. London: London Youth Matters.

12 I. Crewe, T. Fox and J. Alt (1992) 'Non-voting in British general elections, 1966 - October 1974', in D. Denver and G. Hands (eds), Issues and Controversies in British electoral Behaviour. London: Harvester Wheatsheaf, p.23-.

${ }_{13}$ Crewe et al., Ibid, p.26.

${ }^{14}$ See also G. Parry, G. Moyser and N. Day, (1992) Political Participation and Democracy in Britain. Cambridge, Cambridge University Press, p.84, who agree that 'more education tends to mean more participation'.

${ }^{15}$ Helen Wilkinson (1996) 'But will they vote? The political attitudes of young people', Children and Society, 10:3, p.242.

${ }^{16}$ Geoff Mulgan and Helen Wilkinson (1997) 'Freedom's Children and the Rise of Generational Politics', in G. Mulgan (ed) Life after Politics: New thinking for the twenty-first century. London, Fontana Press, p.218.

${ }_{17}$ Mulgan and Wilkinson, Ibid, p.220.

${ }^{18}$ Parry et al., Ibid, pp.262-3.
} 
Apart from Parry and his colleagues' work there is a growing body of scholarship challenging the notion that those disengaged from formal politics are somehow necessarily detached from the wider democratic process. For their part Roker and Player question the preoccupation with youth participation in conventional politics, most obviously through the ballotbox. Having gathered data from a multi-area school survey of 14-16 year-olds, the authors challenge the image of young people as alienated, disaffected and selfish. ${ }^{19}$ Significantly they uncovered a high level of voluntary and campaigning activity amongst the young people they interviewed with respondents typically not regarding what they were doing as necessarily 'political'.

Similarly in her ethnographic study, Kum Kum Bhavnani raises the possibility that the young people she talked with could have provided instances of activity which they themselves may not have defined as 'political' but which could be placed within the domain of politics. In a series of enlightening passages it is quite clear that, for Bhavnani's subjects, 'politics' as represented by parties and politicians simply does not connect with their everyday lives in any meaningful way. Of the views expressed in her interviews, three keep reappearing: 'that politics is boring, that politics is difficult to understand, and that there was no point in voting'. ${ }^{20}$ In another study of young people Gaskin, Vlaeminke and Fenton also found that whilst their subjects tended to 'show a distinct alienation from mainstream politics' these people also saw work with 'voluntary organisations as a route to social and political action. ${ }^{21}$

When it came to formal politics Roker and Player attempted to gauge their sample's interest by asking which party they felt closest to: only $29 \%$ actually identified a party, with the remaining $71 \%$ responding either 'not sure' or 'none'. ${ }^{22}$ Published in the same election year, an Industrial Society sponsored report found that a minuscule $2 \%$ of those 12 to 25 year olds surveyed had an affinity with any political party. ${ }^{23}$ Figures such as these have sometimes been used to characterise young people as being disengaged from society and politically illiterate. London Youth Matters, an umbrella organisation representing a myriad of groups in the capital, contend that critics have been too ready to use limited data to attack a youth population which has become a 'soft target for those wanting to jump on the moral bandwagon... a scapegoat generation'. ${ }^{24}$

Disengagement from formal politics is by no means a new phenomenon. A similar theme can be found in the earlier literature, particularly during the 1970s when scholars such as Marsh used survey data to argue that people regarded politics as 'a remote and unresponsive system run by cynical and aloof politicians'. ${ }^{25}$ A similar line of analysis underpins Bynner and Ashford's more recent survey of young people's attitudes: when questioned one third of respondents thought politicians were only in politics for their own benefit; upwards of a sixth believed that it did not make any difference which party was in power; and a fifth endorsed the view that 'none of the political parties would do anything for me'. ${ }^{26}$

Aside from the academic commentaries on youth citizenship, several sectional interest organisations have devoted time and resources to the subject. This preoccupation reflects a wider public concern. The TUC's 1996 publication, Testament of Youth, portrays widespread apathy about the political process amongst the nation's young in the context of concerns about low pay, poor training and declining trade union membership. A specially commissioned Gallup survey, on which their report is based, suggested that only $40 \%$ of 18 -24 year-olds were certain or very likely to vote in the forthcoming general election. The report also quoted an earlier NOP survey for the TUC in which $69 \%$ of young people say that politicians understand either 'not very well' or 'not at all' 'what working life today is really like,. ${ }^{27}$ Similarly, the $12-25$ year-olds questioned as part of the Industrial Society backed 2020 Vision Programme regarded politicians as 'pointlessly argumentative, out of touch with young people, untrustworthy and uncaring, and obsessed with economic policy at the expense of social policy, ${ }^{28}$

${ }^{19}$ D. Roker and K. Player (1997) 'Challenging the image: Young people as volunteers and campaigners', Youth Action, No. 60, p.11. Study for The Trust for the Study of Adolescence.

${ }^{20}$ Kum Kum. Bhavnani (1994) Talking Politics: a psychological framing of views from youth in Britain. Cambridge, Cambridge University Press, p.139.

${ }^{21}$ K. Gaskin, M. Vlaeminke and N. Fenton (1996) Young People's Attitudes Towards the Voluntary Sector: A Report for the Commission on the Future of the Voluntary Sector. Loughborough: Lougborough University.

${ }^{22}$ Roker and Player, op.cit.

${ }^{23}$ The Industrial Society (1997) Speaking Up Speaking Out!: The 2020 Vision Programme Summary Research Report. London: Industrial Society, p.13.

${ }^{24}$ London Youth Matters (1997) The Kids are Alright? What it's like to be young in London in the 1990's. London: London Youth Matters, p.4. The report goes on to provide a evidence from a range of organisations documenting young people's experience of crime, unemployment and poverty, and their lack of skills, qualifications and opportunities to account for their 'fractured' experiences. The document quotes data and statistics from, amongst others, the Volunteer Centre UK, TUC, British Youth Council, BBC, Youth Aid, and NACRO.

${ }^{25}$ A. Marsh (1977) Protest and Political Consciousness. London: Sage, p.115.

26 J. Bynner and S. Ashford (1994) 'Politics and participation: Some antecedents of young people's attitudes to the political system and political activity', European Journal of Social Psychology, 24:2, p.227.

27 Trades Union Congress (1996) Testament of Youth: A Manifesto for Young Workers. London: TUC.

28 The Industrial Society, op.cit, p.13. 
Though most of the literature suggests politicians cannot be trusted, young people still appear to have faith in representative democratic government. As Heath and Topf have pointed out, there is a critical difference between people's attitudes towards parties (and the politicians who lead them) as distinct from the democratic process. This demarcation is consistent with Axford and Huggins' characterisation of young people as 'disenchanted democrats' ${ }^{29}$

\section{7: a turning point in youth socialisation?}

Curtice and Jowell report that the concluding years of Conservative rule were marked by a widespread sense of falling confidence in politicians and the political system they represent. Significantly, whilst they identify a very low regard for the system and its custodians, they do not suggest that this declining confidence has led to a more alienated electorate. $^{30}$ On the contrary, they find relatively high levels of public self-confidence. Furthermore they suggest that those who have lost confidence in the political system seemed to be responding by wanting to change it rather than withdrawing from it. Linked to this they found a 'growing tolerance of unconventional political action by others'. ${ }^{31}$

Having re-interviewed respondents following the 1997 General Election, Curtice and Jowell also suggest that the poll result may have, albeit temporarily, increased some of the electorate's sense of hope and optimism about the future. $^{32}$ It is a mood the New Labour government has been keen to promote. Critically, ministers have attempted to demonstrate their willingness to listen to different groups. Britain's youth, in particular, have been well courted. ${ }^{33}$ Indeed this follows on from statements made by Tony Blair prior to the election, notably the one in which he declared he would rather young people participate and vote against Labour than not at all. ${ }^{34}$ That said Blair, not to mention his main opponents, did appear to have other preoccupations; as Kimberlee notes: 'most of the election campaign centred around the concerns of middle-aged homeowners in the key marginal constituencies'. ${ }^{35}$ When politicians did address issues of concern to young people they tended to do so 'too often from their parents' perspective'. ${ }^{36}$

Blair's rhetoric about a 'Young Country' did appear to strike a chord with the electorate and especially youth. Within a year of Labour's election victory the new government did however find itself in conflict with sections of the younger population angered by new policy initiatives on education, employment, drugs and other matters. Formerly supportive music artists articulated this disappointment. In one dramatic intervention a member of the group Chumbawamba drenched John Prescott with water at an awards ceremony. ${ }^{37}$ A month later the New Musical Express published damning commentaries on Labour's performance from many of those who had supported the party's election campaign. ${ }^{38}$ Government supporters appeared worried by the NME article. Several helped launch a counter offensive with one former candidate offering the riposte: 'That a collection of spoiltbrat, coke-snorting millionaire pop stars with the attention span of a goldfish have decided they've had enough of the Labour Government should cause no lost sleep' ${ }^{39}$ Whatever their effect on opinion comments from both sides, together with the media debate that followed, helped promote the idea that young people's concerns were no longer peripheral to the political agenda.

'No, we played a big gig on election night and my keyboard was covered in 'Vote Labour' stickers. A couple of months later I'd ripped them all off. We all had high hopes, but they don't seem to be doing much... for

\footnotetext{
${ }^{29}$ Axford and Huggins, op.cit., p.2.

${ }^{30}$ Only $22 \%$ of the electorate trust governments to put the interests of the nation above that of party, $28 \%$ agree with the statement that 'parties are only interested in peoples votes, not their opinions', and over a quarter of the population now strongly agree that 'political parties and MP's are out of touch with the needs of the electorate'. See John Curtice and Roger Jowell (1997) 'Trust in the political system', in R. Jowell et al., British Social Attitudes: The 14th report. The end of Conservative values? Aldershot, Ashgate, p.92.

${ }^{31}$ Curtice and Jowell, Ibid, p.94.

32 Ibid, p.106.

${ }^{33}$ See, for example, Peter Mandelson's argument that the Labour Party is different and can make a difference. "A lifeline for youth", The Guardian, 15 August 1997.

34 'Parties make their pitch to attract youth vote', The Guardian, 31 January 1997.

${ }^{35}$ R. Kimberlee (1998) 'Young People and the 1997 General Election', Renewal, 6:2, p.89.

${ }^{36}$ M. Leonard and S. Katwala, 'It was the young wot won it!', Renewal, 5:314, p.112.

${ }^{37}$ Chumbawamba vocalist Danbert Nobacon claimed that he did it 'on behalf of single mothers, pensioners, sacked dockers, people being forced into "workfare", people who will be denied legal aid, students who will be denied the free university education that the entire front bench benefited from, the homeless and all the underclass that are now suffering at the hands of the Labour government', 'Betrayed: The Labour Goverment's war on you', New Musical Express, 14 March 1998, p.28.

38 Ibid, p.31.

39 Letter from Paul Richards, The Guardian, 16 March 1998.
} 
some reason they seem to think that they're the party of the youth. But people aren't stupid and I think people will think less of them for it. ${ }^{40}$

Government supporters appeared worried by the NME article. Several helped launch a counter offensive with one former candidate offering the riposte: 'That a collection of spoiltbrat, coke-snorting millionaire pop stars with the attention span of a goldfish have decided they've had enough of the Labour Government should cause no lost sleep'. ${ }^{41}$ Whatever their effect on opinion comments from both sides, together with the media debate that followed, helped promote the idea that young people’s concerns were no longer peripheral to the political agenda.

\section{Research Design}

This study was designed to yield a representative sample of first time voters across Nottinghamshire. We focused exclusively on 'attainers', defined as men and women who were 18 years old at the time that the electoral register was compiled (October 1997) and 17 year olds who would be eligible to vote by the time that the electoral register came into force (February 1998). These attainers are clearly identified on electoral registers. Of course, not every attainer would be captured by this method - indeed, approximately 14\% of 18-19 year olds are not registered to vote, which compares with only 2 per cent of those aged 50 or above. ${ }^{42}$ Nonetheless, the vast majority of our target group was eligible for inclusion through this method.

Our intention in limiting our study to attainers was twofold. Firstly, they would have no formal experience of participating in elections, and therefore have had no opportunity of expressing party preferences through voting, or of casting their verdict on the political parties and all that they stand for. In this sense, these attainers are relatively inexperienced politically compared to older people, ${ }^{43}$ and as such they provide a fascinating target group for study in terms of their perception of politics, parties and politicians in Britain.

Secondly, in research terms, attainers are a relatively unique target group. Most social and political surveys that examine the views of young people tend to combine their views with older youths. Hence, attainers will be analysed as part of an 18-24 (or 18-25) year old group ${ }^{44}$ or included in studies of students, typically alongside respondents with an increasingly mature age profile as Higher Education is opened up to new entrants.

Nottinghamshire was chosen because it represents the archetypal local economy in transition. There has been a decline in heavy industry within the county as epitomised by the collapse of the local mining industry. Similarly there has been a shift of investment from power generation, textiles and engineering and into new technology based and service industries. In turn this has led to a marked change in shape of the labour market with an increasingly middle class, white-collar professional group as well as pockets of high and long-term unemployment. According to the local authority, the number of jobs within the county declined by 5\% between 1991 and 1995, while male earnings fell to $13 \%$ below the national average, with youth unemployment of particular concern. ${ }^{45}$ Nottinghamshire is also interesting because it has been relatively marginal in local and national political terms throughout the 1980s. Indeed it has a post-war electoral history as a largely settled adversarial two-party political system, although it is now a predominantly 'Labour' area. ${ }^{46}$ Thus, in terms of the views of its young attainers, Nottinghamshire is likely to serve as a useful barometer for the country as a whole.

We used a random sampling method, stratified by the eight local authority districts in the county, and with respondents drawn from the electoral register. Of the 7,958 attainers across the county, it was decided to include 5,000 young attainers, a 63\% sample. Respondents were mailed a questionnaire direct to their home address in midJune 1998.

The actual size of the sample gained was 1,597 from the 5,000 attainers included in the study, a response rate of $32 \%$. This response rate can be put into context by comparing it with the voting turnout for the county as a

\footnotetext{
40 Ibid, p.31.

${ }^{41}$ Letter from Paul Richards, The Guardian, 16 March 1998.

42 S. Arber (1993) 'Designing Samples', in N.Gilbert (ed.) Researching Social Life. London: Sage; p.81.

${ }^{43}$ This is not to suggest that these attainers are politically naive. Elections are certainly the most commonly used means for participating in politics in Britain. But these young people will have experienced politics indirectly through the mediation of journalists and broadcasters. In addition some of them may have taken part in politics by joining campaigns, movements and party youth wings or carried out political acts through other informal means such as petitions, donations and so on.

${ }^{44}$ For instance, see Parry et al, Ibid, which is a study of 'relatively young adults' (p.156) who are between 18 to 29 year of age.

45 Nottinghamshire County Council (1996) Building Together: Strategic Plan 1997-2001. Nottinghamshire: Nottinghamshire County Council.

${ }^{46}$ Mike Young, Matt Henn and Neil Hill (1997) 'Labour Renewal Under Blair? A Local Membership Study in Middleham', in J.Stanyer and G.Stoker (eds), Contemporary Political Studies. Exeter: Political Studies
} Association, p.499. 
whole, and for each of the eight local authority districts. We would expect of course that people are more likely to participate in elections (where their vote has some influence over local decision-making) than in our survey (where their response does not). We found that, contrary to our expectations, there was only a marginal difference between the two. Furthermore, our survey contains only the views of 17 and 18 year olds; as young people are less likely to vote in elections than older age-groups, we can assume that if we had voting details for this age group, the turnout would be considerably lower, and therefore closer to our survey response rate. Our overall response of $32 \%$ is only marginally less than the percentage turnout for the last county-wide council elections (1993) when the turnout for all voting adults was 35.9\%. 


\section{Results}

This study has attempted to gain an understanding of how young people relate to political institutions and processes. Respondents were asked for their opinions of politicians and political parties. Furthermore the survey gathered replies to a set of more wide-ranging questions concerning the sample's more general attitudes, or civic orientation, to politics. In one item respondents were encouraged to identify the topic of most concern to them, thereby giving some definition and substance to the salient issues as well as what young people believe politics to be essentially about. Aside from this, respondents were also questioned about how much they discussed the subject, their levels of activity, and their consumption of local media.

\section{Political Engagement}

Our research reveals evidence that, far from being apolitical and apathetic, young people are interested in political issues. Firstly, we found that there was a clear majority of people (over 80 percent) who discuss politics with friends and family (see table 1 ). When asked about national politics, nearly two thirds (60.1\%) of respondents replied that they had some or more interest in the topic; few admitted to having none at all (14.2\%). There was, however, less engagement with local issues: just over two fifths (41.2\%) said they had at least some interest, approximately twice the number who had none (20.9\%). 
Table 1

Attainers Political Engagement (\%)

\begin{tabular}{|c|c|c|c|c|c|}
\hline & $\begin{array}{l}\text { A great } \\
\text { deal }\end{array}$ & $\begin{array}{l}\text { Quite } \\
\text { a lot }\end{array}$ & Some & $\begin{array}{l}\text { Not very } \\
\text { much }\end{array}$ & $\begin{array}{l}\text { None/ } \\
\text { not at all }\end{array}$ \\
\hline $\begin{array}{l}\text { Generally speaking, how often would you say that } \\
\text { you talk about politics with your friends or family? }\end{array}$ & 2.9 & 12.6 & 30.5 & 35.1 & 18.9 \\
\hline $\begin{array}{l}\text { How much interest do you nromally have in } \\
\text { national politics? }\end{array}$ & 4.8 & 18.6 & 36.7 & 25.7 & 14.2 \\
\hline $\begin{array}{l}\text { How much interest do you normally have in local } \\
\text { politics? }\end{array}$ & 1.6 & 7.7 & 31.9 & 37.9 & 20.9 \\
\hline
\end{tabular}


The interest respondents had in politics manifested itself in various ways. When asked what they thought was the most important issue, ${ }^{47}$ respondents who replied tended to focus on education, followed by international matters, the environment, general politics, economics and other topics in that order (see figure 1 below). The responses were generally well-thought through, and typically the young participants within the survey recorded quite detailed and sophisticated answers. Furthermore, we received only one sardonic response, "England to win the World Cup"; given President Chirac's immediate poll ratings boost in the aftermath of France's victory in the football competition this year, this is perhaps not such a non-political indicator afterall.

\section{Figure 1 Agenda of Youth Concerns}

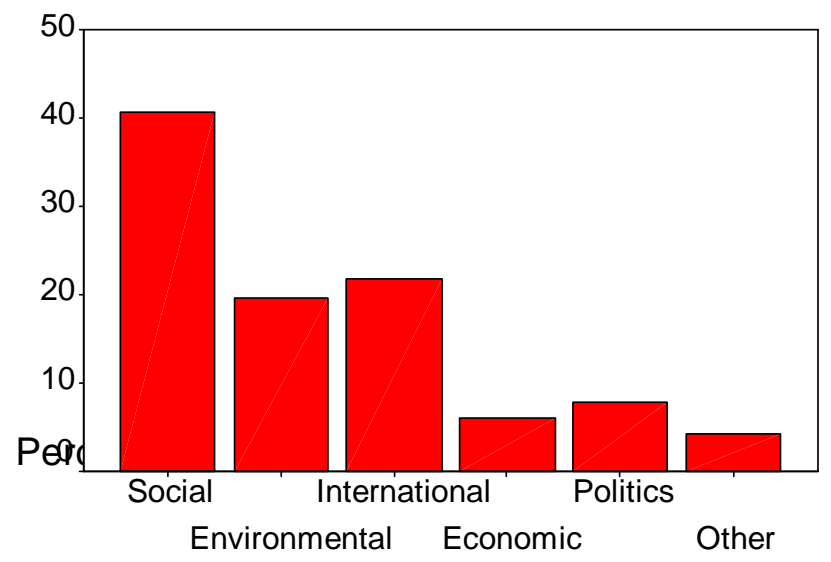

\section{Confidence in the Political Process}

Young people clearly have a strong commitment to the democratic process. Three quarters of those included in the survey stated that it was important to vote in national elections (75.6\%), and perhaps surprisingly given the low turnout in recent contests, two-thirds claimed the same for local elections (64.3\%). Significantly, twice as many attainers admitted they strongly agreed when asked about the former (32.9\%) as against the latter type of contest (18.7\%). Only a fraction responded that voting in both national (3.4\%) and local (4.2\%) elections was not important. This apparent faith in the electoral process is reinforced by the low figure for those who expressed the view that "voting is a waste of time" (4.8 percent) and the high number who disagreed (73.6 percent) with this contention (see Table 2).

47 We asked an open question: 'Which community, national or international issue are you most concerned about?'. We created six categories from this question. Full details including other technical aspects of the project can be obtained from the authors on request. 
Table 2

Perception of Importance of Voting (\%)

How much do you agreed or disagree with Strongly

Agree Neither Disagree

/nor

Strongly each of the following statements?

agree

disagree

Important to vote in national elections

$32.9 \quad 42.721 .0 \quad 2.2$

Important to vote in local elections

$18.7 \quad 45.631 .4 \quad 3$.

1.2

Voting is a waste of time 
Reflecting the fluctuating levels of turnout in different polls, $21.9 \%$ replied that they did not know whether they would vote in the next national election, rising to $35.6 \%$ when the question was asked of local contests and $42.2 \%$ in relation to the European Assembly race (see Table 3). A small minority claimed that they would not participate in general (8.5\%) or local (9.9\%) elections at all, with nearly twice as many intending to abstain in the next poll for the European Assembly (20.7\%). These results suggest that young people are not naively over-generalising their support for elections. They are discriminating supporters of the democratic process, with considerably fewer recognising an importance in voting at European elections compared to local or national contests. This may be due to the perceived remoteness of the European Assembly from their lives. 
Table 3 Intention to vote, and party identification (\%)

Yes

Do you intend to vote in the next parliamentary general election? 69.6

Do you intend to vote in the next local election?

54.5

Do you intend to vote in the next European parliamentary election?37.1

If you do intend to vote (in the next parliamentary general

election), do you know which party you will vote for?

If you do intend to vote (in the next local election) do you know 35.7

which party you will vote for?

If you do intend to vite (in the next European parliamentary

election), do you know which party you will vote for?

\section{No}

8.5

9.9

20.7

59.0

80.2 
Of those who intended to vote in a national election, only $41.0 \%$ knew which political party they would support, as against a clear majority (59.0\%) who did not. The figures for local elections were similar, with slightly less (35.7\%) reporting that they knew who they would support as against nearly two thirds who did not (64.3\%). The degree of uncertainty was even more noticeable for the European elections, with only $19.8 \%$ admitting to knowing which party they would vote for compared with over four fifths who did not (80.2\%). This trend perhaps bares out the marked tendency for greater shifts of allegiance amongst those going to the polls for elections to the European Assembly. Nevertheless there is still evidence of potential and substantial young voter volatility in the non-European contests.

\section{Political Activism}

Perhaps predictably, given their relative youth, the attainers were rather inexperienced politically (see table 4). Only a fraction admitted to having joined a political party (1.1\%) in the past. When asked whether they might ever consider becoming a member, only $7 \%$ of respondents thought they were likely to do so. A majority of two thirds (66.3\%) replied that they thought it unlikely, but another $26.6 \%$ admitted they did not know, suggesting they were open to persuasion in the future. Though a minority, there appears to be a sufficient number of members and potential joiners to service political parties and thus enable them to survive with at least a rudimentary structure. 
Table $4 \quad$ Political Activism (\%)

Have you ever joined a political party?

$1.1 \quad 98.9$

Have you ever written to your Member of Parliament?

Have you ever written to your local councillor?

$10.2 \quad 89.8$

Have you ever joined a campaign group?

$6.8 \quad 93.2$

Have you ever signed a petition?

Have you ever given money to a campaign

$\mathbf{1 1 . 3} \mathbf{8 8 . 7}$

Have you ever taken part in a march or demonstration?

82.6

$14.4 \quad 85.6$ 
Just over a tenth of respondents (10.2\%) said they had written to their MP. Marginally more agreed they were likely to do so in the future (14.2\%) against a substantial proportion who said that this was unlikely to happen (40.5\%). Similarly, relatively few (6.8\%) admitted to having written to any local councillors with nearly twice that (10.1\%) agreeing they were likely to do so in the future as against two fifths who were not (39.6\%).

The pattern of dislocation from formal politics is continued when respondents were asked for their opinion of politicians. Only a minority (18.5\%) agreed that politicians cared for young people like themselves with over double that (38.6\%) saying they did not, and a comparable number (42.9\%) not knowing one way or the other. Similarly under a fifth (16.5\%) disagreed with the contention that, once elected, politicians lose touch suggesting substantial scepticism, even cynicism, with formal politics, parties, and their elected representatives. This is borne out by the significant minority (47.2\%) who supported the statement, though just over a third (36.3\%) admitted to having no decisive opinion on the matter. Larger majorities agreed with other assertions which were roundly critical of parties, notably the statement that parties are interested in votes not opinions (52.2\%) and that it doesn't matter who is in power things go on much the same (51.4\%) as against dissenters on these topics (17.5\% and $28.0 \%$ respectively).

Somewhat surprisingly, however, when asked whether they thought politicians were all the same nearly half (47.7\%) dissented from this view as opposed to a sceptical quarter of the sample who agreed with the statement (27.1\%), and those who had no opinion either way (25.2\%). 
Table 5 Youth Perception of Formal Politics (\%)

How much do you agree or disagree with each of the following statements?

Politicians care about young people like myself

Politicians are all the same

Once elected, politicians lose touch with people pretty quickly

Parties are only interested in people's votes, not in their opinions

It doesn't matter which party is in power, in the end things go on

much the same
Agree Neither/ Disagree

Nor

$\begin{array}{lll}18.5 & 42.9 \quad 38.6\end{array}$

$\begin{array}{lll}27.1 & 25.2 & 47.7\end{array}$

$47.2 \quad 36.3 \quad 16.5$

$\begin{array}{lll}52.2 & 30.3 \quad 17.5\end{array}$

$51.4 \quad 20.6-28.0$ 


\section{Other Indicators of Political Activism.}

When asked whether they had ever joined a campaign group, those who had were in a clear minority (11.3\%), though, as we have seen, this was substantially more than the small number who had belonged to a party. Marginally more admitted that they were likely to join one in the future (12.9\%) though the most sizeable group (39.3\%) said they did not know. The reticence of many to commit themselves to a group did not mean they were unwilling to participate in some way or another and, in fact, could be interpreted to suggest that they were openminded about this idea. A substantial majority (82.6\%) said they had signed a petition and only a minority ruled this out in the future (5.2\%). Nearly half (46.1\%) admitted to having given money to a campaign in the past, and $14.4 \%$ of respondents had participated in a march or demonstration. Interestingly only a third (31.2\%) said they were unlikely or extremely unlikely to participate in this type of direct action in the future.

Respondents were asked a series of questions on specific single-issue campaigns. Besides differing aims, these initiatives have used a variety of advertising media and awareness-raising techniques. Nevertheless all were of some interest to young people. The first of these, a health campaign called Drugs Abuse Resistance Education (D.A.R.E.), was originally pioneered in Nottinghamshire between 1993 and $1996 .{ }^{48}$ Similarly Stick it in the Box, a council initiative to increase youth turnout, was launched throughout the county in anticipation of the 1997 local and Westminster elections. ${ }^{49}$

The other two campaigns were run on a national basis prior to the last General Election in 1997. These were Operation Black Vote, which aimed to increase electoral participation amongst ethnic minority voters, and the Rock the Vote initiative mentioned in the introduction to this paper. The latter slogan, devised for a campaign pioneered in the United States during the run-up to the 1996 presidential race, was adopted by the British music industry as a means of increasing young voter registration and awareness before the 1997 election. The first national campaign of its kind, it enjoyed the sponsorship of several celebrity patrons together with a relatively high presence in the media regularly consumed by youth. ${ }^{50}$

Asked whether they knew about any of these campaigns, just over a fifth (21.0\%) recognised Stick it in the Box as against a majority who did not (73.6\%). Surprisingly perhaps nearly all of the respondents (95.6\%) said they had heard of D.A.R.E. By comparison only $8.7 \%$ of survey respondents admitted to having heard of Rock the Vote as against the overwhelming majority (88.4\%) who had not. The numbers who had heard of Rock the Vote were only marginally more than the $7.3 \%$ who said they knew of the lower profile and, by its nature, more specialised Operation Black Vote.

The higher recognition rates for the local campaign initiatives suggest regional rather than national organisations may be in a better place to communicate with young people. This point is arguably reinforced by respondents' own non-national media use. Questioned about their weekly viewing and listening habits, more than three quarters (78.1\%) admitted to viewing local/regional news programmes at least twice a week. Whilst the numbers who never listened to local/regional news on the radio formed a sizeable minority (19.5\%), over half (51.3\%) tuned in twice or more every week. Most respondents also read the local/regional press at least once or more every week (83.2\%) as against barely one in twenty (5.9\%) who never do so.

\section{Conclusion}

Contrary to the perception of some media commentators, the survey has assessed the attitudes of young, potential first time voters and uncovered a group with an interest in political issues if not the formal institutions associated with them. It has been argued that there is a civic orientation amongst the young to the democratic process, but an antipathy to formal, professional politics. This trend is most marked when significant numbers of respondents confessed to having been involved in minimal, politically related activities such as giving money, petition-signing, and even attendance at demonstrations. These approaches perhaps reflect the sample's concern with issues relating to the environment, education and international affairs.

It was seen that respondents divided into two smaller groups of the activist and alienated aside from a clear majority who may appear less motivated but displayed important signs they were engaged with the democratic process. This was most clear when a large proportion of those questioned expressed some desire to take part in elections. The commitment was especially marked in the case of national and local contests if not for the forthcoming European Assembly poll. Significantly, the apparent concern with regional politics was further borne

\footnotetext{
48 The campaign was aimed primarily at children aged 9 to 11 , typically the younger siblings of the sample surveyed here. Whilst most of the work was done in Nottinghamshire schools there was also some advertising and media publicity throughout the county. Gill Empson (1997) 'DARE you be inspected', Teaching Today, summer.

${ }^{49}$ The campaign, managed by Nottinghamshire County Council, ran throughout April 1997 with the key slogan appearing on hoardings, buses and in newspaper advertisements. In addition 6,000 leaflets were distributed around the county's schools and colleges.
}

${ }^{50}$ Cloonan and Street, Ibid. 
out by other results. When asked about their media use, most respondents watched, listened or read local news sources on a regular basis. Added to this, more agreed that they had heard of the regionally based campaigns than the similar national initiatives aimed at them. 